\title{
Influence of Municipalities on LAG's Effectiveness in Attracting Project Subsidies in Croatia
}

\author{
ŽELJKO MRNJAVAC \& IVANA PERIĆ
}

\begin{abstract}
Local Action Groups LAGs are tri-sectoral bodies in which the economic and civil sectors in partnership with the public sector use EU policy funds for rural development. In such a decentralized approach to communityled local development, there is a risk of excessive municipal interference and principles of bottom-up development can be compromised. The basic assumption by which the leading public sector is trying to justify itself as having a better administrative capacity that can help LAGs to attract and absorb subsidies is statistically tested in this paper. Example of Croatia has shown that "municipalization" of local partnerships have no justifications, as increasing the share of public partners in the membership structure reduces LAG effectiveness in attracting project subsidies, and in the same time municipalities that prove stronger absorptive capacity through larger share of EU funds in their budget, show no positive influence transferred to LAGs in which they are members.
\end{abstract}

Keywords: • local action group $\bullet$ local development $\bullet$ LAG's effectiveness - project subsidies $\bullet$ Croatia

Correspondence AdDress: Željko Mrnjavac, Ph.D., Professor, University of Split, Faculty of Business and Turism, Cvite Fiskovića 5, 21000 Split, Croatia, email: zeljko.mrnjavac@efst.hr. Ivana Perić, OPG Miletić - SPARA, Gizdići 33, Klis, Croatia, email: opg.spara.klis@gmail.com.

https://doi.org/10.4335/18.1.35-52(2020)

ISSN 1581-5374 Print/1855-363X Online (C) 2019 Lex localis

Available online at http://journal.lex-localis.press. 
The idea that socio-economic well-being can be more effective and less costly achieved by focusing on needs and resource valorization at a local level is the underlying concept of the endogenous, and, more recently, the neo-endogenous rural development (Ray 2000, Ray 2006, O’Keeffe 2009, Bosworth at al. 2016, Dax at al. 2016). This discourse that conceives the development as a process that arises from within the local areas, has gained importance not only in academic debate, but it has become the foundation of the current European strategy for a bottom-up regional and rural development (High \& Nemes 2007, Lopolito et al. 2011)

The best example of such strategy is the EU LEADER approach that is based on seven features: (a) area-based local development strategies for rural territories, (b) partnerships in the form of local action groups (LAGs), (c) a bottom-up elaboration and implementation of local development strategies, (d) multi-sectoral approach, (e) innovative approaches, (f) the implementation of cooperative projects, and (g) the networking of local partnerships (CEC 2005, Art. 61). Through this approach in all EU member states have been established LAGs as local tri-sector partnerships for economic diversification and promotion of quality of life in rural areas. These partnerships use financial aid to identify and implement a local development strategy based on the bottom-up approach and to allocate financial resources through grants to local projects. (Teilmann \& Thuesen 2014)

Among these seven key features of the Leader approach, the principle of the local public-private partnerships is especially distinctive one and is realized in the formation of the LAGs by both public and private partners. The creation of publicprivate partnerships can be seen as an innovative model of territorial governance, called "partnership governance" and may be considered as a form of multistakeholder governance (Argiolas et al. 2009). The interaction through cooperative coordination among relevant partners that is fostered by the LAGs should produce disproportionately high benefits relative to the committed resources (Farrel \& Thrion, 2005). But to achieve this advantage, members in LAG should be wellbalanced to represent all of the local interest groups (Lopolito et al. 2011).

The Leader approach gives control of the EU budget to a multitude of LAGs, so compared with traditional ways of funding it involves higher costs and risks because of this additional layer of implementation. These additional costs and risks can be justified only with added value that should flow from better identification of local needs, more engagement of local stakeholders, greater scope for innovation and local solutions that characterize bottom-up and partnership approach. (European Court of Auditors 2010)

Territorial partnerships vary in size and structure (e.g. number of inhabitants, covered area, number of municipalities included, the structure of the economy, 
number of representatives of the civil and economic sector). The Leader implementation, in line with the general idea of public-private partnership, is supposed to involve members from civil (non-governmental) and economic sectors together with local municipalities in decisions about future management and development of a given area. Accordingly, the real involvement of representatives of various sectors in the functioning of any LAG and the distribution of power within these partnerships are extremely important. (Sykala et al. Ed. 2015)

Often are such governance mechanisms used to ensure the continuation of the local elites' hegemony by tending to involve only the key actors belonging to this elite groups (Kovach, 2000; Kovach and Kucerova, 2006, Esparcia 2015). This implies that local government authorities often try to take over control of tri-sectoral partnerships' activities, which was recognized as "colonization" (Knieć 2007) or "municipalization" (Halamska 2011, Lacquement and Raynal 2013, Chevalier et al. 2017) of LAGs by local authorities.

The European Court of Auditors has expressed the criticism that in the LAGs which are dominated by the local authorities in decision-making, the potential added value of a partnership was constrained. (European Court of Auditors 2010)

In the search for an explanation for "municipalization" and "colonization" of local action groups, the significance of two kinds of factors is emphasized (Zajda 2014). Objective one would be that the public sector has the most competent personnel, especially in the field of EU applications. As the effectiveness of LAG depends on the application for funds for their activity, the experience of municipalities with high administrative capacity could strongly influence the absorption of subsidies by LAGs. On the other side subjective factors could be that in small communities, the public sector has a significant informal influence. After forming local action groups, their members can be perceived as competitors in the race for power, which triggers the tendency of public officials to control things as they are afraid to lose their position of the municipality being the institution responsible for local development.

Our aim in this work is to distinguish the liability of a thesis regarding the importance of the administrative capacity which could be transferred into LAG by a public partner using a Croatian example. Publicly released municipality budgets have shown differences in the number of funds from the European Union funds included in the budget, which therefore means that they do not have an equally capable and active public administration for the attracting and for the realization of EU projects. In other words, they do not have the same capacity of absorption for funds that are available to them from the EU programs (Ott et al. 2016, 2018). In the case that the thesis of the importance of administrative capacity transfer into LAG by the public partner is correct, then those LAG's whose municipality partners have a stronger absorption capacity should as well, be more successful than the rest in the absorption of subsidies. 
It should be checked whether or not a quantitative impact corresponds to the above mentioned claims (European Court of Auditors 2010) which state that a large share of the public sector in partnerships decreases their efficacy, can be identified. This could be linked to the number of public partners in the total number of members in every LAG.

Of course, other factors can be of importance for success in absorbing funds through LAGs, as was confirmed by the technical efficiency research of LAGs on a Czech example (Vrabkova \& Šaradin, 2017). The results showed that the population size of an LAG and the number of LAG members influence LAG's efficiency, and consequently they both affect the volume of absorbed subsidies.

During the observation period, projects aimed at the agricultural sector were an important part of LAG's activities. In relative EU programs for local development, these funds for agriculture have a larger share and are more easily available for LAGs. Due to this, it is possible to consider whether or not there is an impact from the economic structure in the LAG area, in other words, the positive impact of a larger share of agricultural employment in absorbing funds and realizing projects through LAG.

If the number of employees in agriculture is included, it would be also good to test the potential impact of the overall employment, although it is not theoretically unambiguous to assume that effect. We may possibly assume that rural areas with a higher employment rate could be more developed and less interested in withdrawing external sources of funding, i.e. local areas with a shortage of jobs are seeking a way to boost employment growth.

Data on absorption capacity (attracted funding), number and membership structure, as well as size, i.e. population number in LAG areas, will be collected from their websites and employment data will be collected from the Croatian Bureau of Statistics. The municipal absorption capacity data will be taken from Ott et al. 2016, 2018 which processed the data on municipal budgets collected by the ministry of finance.

In order to achieve the aims and purpose of this research and examine the hypothesis, research will be done to investigate the influence of the mentioned factors on the success of the LAGs in the Republic of Croatia in absorbing subsidies, using quantitative methodology on publicly available data. Such an approach allows conclusions to be drawn without surveying LAG participants in the field.

Collected data will be processed using the program SPSS 24.0 (Statistical Package for the Social Sciences) and Mc Excel software. 

the Republic of Croatia

The LEADER program was launched in 1991 with the goal to improve the development potential of rural areas, taking into account the differences between rural areas and the environment, as well as the rich local identities. Functioning by using the bottom-up approach, it includes the local community and gathers various projects and ideas, stakeholders and resources for expanding the opportunities of the rural areas. The benefits of such an approach are confirmed by the increase in member countries that have applied the same approach. Furthermore, the fact that this approach is being integrated into all national and regional Programs for rural development opens up new opportunities for the implementation of the LEADER approach on a much larger scale and much broader area for rural area activities. (European Commission, 2006) Since 2007, LEADER has expanded over the entire rural area and as such becomes the responsibility of all member states.

From 2014 to 2020, the LEADER approach has expanded to a Community-led local development - CLLD mechanism which implies the inclusion of local partners, including representatives of the civil and economic sector, and is implemented through integrated and multi-sectoral local development strategies designed in a way that includes local needs and potentials, including innovative development opportunities, networking, and collaboration. The CLLD mechanism provides more flexibility without too many barriers. By Regulation (EU) No. 1305/2013 of the European Parliament and of the Council of 17 December 2013 on rural development support from the European Agricultural Fund for Rural Development (EPFRR) LAGs are defined as holders of the CLLD approach (through the implementation of their Local Development Strategies). (Croatian LEADER Network)

The implementation of the LEADER approach in Croatia started in 2013 under the implementation of Measure 202 of the IPARD Pre-Accession Program 2007-2013. Through two tenders, for the implementation of the LEADER program, 43 LAGs in the Republic of Croatia were approved, covering 69\% of the territory of the Republic of Croatia where $42 \%$ of the total population lives. After Croatia joined the European Union, more precisely on May 26th, 2015, the European Commission approved the Rural Development Program of the Republic of Croatia for the period 2014-2020. The Program defined 20 measures aimed at increasing the competitiveness of Croatian agriculture, forestry and processing industries, but also the improvement of living and working conditions in rural areas in general. Its total allocation amounts to EUR 2.383 billion, of which EUR 2.026 billion is funded by the European Agricultural Fund for Rural Development (EAFRD) and the rest from the State Budget of the Republic of Croatia. (Ministry of Agriculture, 2014)

Out of the above mentioned 20 measures, we point to Measure 19 whose users were aforementioned LAGs. Within Measure 19, the LEADER approach has been 
preserved and the role of LAGs has become even more important factor of development responsible for the selection of projects which will be funded in the area of its activity. In Croatia, the amount of funds from measure 19 is also increasing every year so LAGs importance grows further.

There are 56 LAGs in Croatia. They cover a surface area of $52,190.05 \mathrm{~km}^{2}$, which makes up $92.30 \%$ of the total area of Croatia. In the LAG area, there are 2,446,567 inhabitants, which make up $57.10 \%$ of the total population of Croatia. The Croatian LAGs include 531 units of local self-government (121 cities and 410 municipalities), accounting for $95.50 \%$ of the total number of local self-government units in Croatia. (HMRR, 2017)

\section{$3 \quad$ LAG's success variables}

This paper analyses the absorption capacity of LAGs, more precisely the impact of several selected variables on LAG's successes to attract and absorb funds from the European Union programs. The variables that will be analyzed in this chapter are:

- LAG size measured by the number of inhabitants in the area,

- Number of members,

- Membership structure (public, economic and civil sector),

- Economy structure (total number of employees and number of employees in agriculture).

In Table 1 are shown all the variables together with the expected influence on the dependent variable.

Table 1: Display of variables and their effect on the dependent variable

\begin{tabular}{|c|c|c|c|c|}
\hline \multicolumn{2}{|c|}{ Variable name } & Abbreviation & Source & $\begin{array}{c}\text { Expected } \\
\text { effect }\end{array}$ \\
\hline \multicolumn{2}{|c|}{$\begin{array}{l}\text { Absorption capacity- } \\
\text { amount of aid that LAG } \\
\text { withdrew from the EU } \\
\text { funds }\end{array}$} & Ab.cap.LAG & $\begin{array}{l}\text { On internet websites } \\
\text { APPRRR (Croatian } \\
\text { Paying Agency for } \\
\text { Agriculture, Fisheries } \\
\text { and Rural Development) }\end{array}$ & $\begin{array}{l}\text { Dependen } \\
\text { t variable }\end{array}$ \\
\hline \multicolumn{2}{|c|}{$\begin{array}{l}\text { Size (number of } \\
\text { inhabitants) }\end{array}$} & Siz. & $\begin{array}{l}\text { On internet websites } \\
\text { HMRR (Croatian Rural } \\
\text { Development Network) }\end{array}$ & + \\
\hline \multicolumn{2}{|c|}{ Number of members } & Num. & $\begin{array}{l}\text { On internet websites } \\
\text { LAGs }\end{array}$ & + \\
\hline \multirow{2}{*}{$\begin{array}{l}\text { Membership } \\
\text { structure }\end{array}$} & $\begin{array}{l}\text { Public } \\
\text { sector }\end{array}$ & PS & \multirow{2}{*}{$\begin{array}{l}\text { On internet websites } \\
\text { LAGs }\end{array}$} & - \\
\hline & $\begin{array}{l}\text { Civil } \\
\text { sector }\end{array}$ & $\mathrm{CS}$ & & + \\
\hline
\end{tabular}




\begin{tabular}{|c|c|c|c|c|c|}
\hline & $\begin{array}{l}\text { Economic } \\
\text { sector }\end{array}$ & ES & & & + \\
\hline \multirow[b]{2}{*}{$\begin{array}{l}\text { Economic } \\
\text { structure }\end{array}$} & $\begin{array}{l}\text { Employee } \\
\mathrm{s}\end{array}$ & Emp. & $\begin{array}{l}\text { Croatian } \\
\text { Statistics }\end{array}$ & Bureau of & - \\
\hline & $\begin{array}{l}\text { Employee } \\
\mathrm{s} \text { within } \\
\text { agricultur } \\
\mathrm{e} \text {, forestry } \\
\text { and } \\
\text { fishing }\end{array}$ & Emp.agr. & $\begin{array}{l}\text { Croatian } \\
\text { Statistics }\end{array}$ & Bureau of & + \\
\hline
\end{tabular}

Source: authors

From the analysis of the data that was collected, the following can be highlighted.

The largest number of LAGs (64.29\%) withdrawn between 1 and 1.5 million Euros from EU funds in the period from 2013. to 2018. There are $11.64 \%$ of LAGs who withdrew less than 1 million Euros for their area of activity and $16.07 \%$ who were the most effective with more than 1.5 million Euros.

There is also a difference in the number of inhabitants, i.e. the size among the LAGs. On the one hand, there are $16.07 \%$ LAGs with up to 20,000 inhabitants, while on the other hand there is $14.29 \%$ with just over 80,000 inhabitants. The largest number of LAGs, $69.64 \%$ of them, have between 20,000 and 80,000 inhabitants. Since membership in LAGs can only be accessed by cities and municipalities with less than 25,000 inhabitants, it is clear that they are LAGs with multiple local selfgovernment units that merged through membership in Local Action Groups, all with the goal to develop their territory easier.

LAGs also vary by the number of members. The largest number of LAGs $(52.78 \%)$ has between 50 and 100 members. Significant is the number of LAGs, $30.55 \%$ of them, with less than 50, while the smaller number has slightly more than 100 members, and is $16.67 \%$.

Most of the funds that LAGs can apply for from the European Funds are allocated towards agriculture, forestry, and the fishing sector. For this reason, employment in this sector was taken as one of the influential variables. so the share of employees in agriculture in the total number of employees was observed. There are LAGs with a share below 5\% (26.08\%), but also those whose share exceeds $15 \%(23.91 \%)$. The other $50.01 \%$ have between 5 and 15 percent of employees in agriculture, forestry and the fishing sector in the total number of employees. So, variations in distribution make possible to look at the impact of this variable too.

Table 3 represents standard descriptive statistics indicators: number of arithmetic means, median, mode, standard deviation, range and minimum, and maximum variables values. For the 56 local action groups observed, the average value of 
subsidies received from the EU is 1,196,820.28 Euros. By calculating the median for the above variable, we see that $50 \%$ of LAGs received less than 1,205,189.14 Euros, while the other $50 \%$ absorbed more.

From the standard deviation amount we see that the average deviation from the average is $338,338.00$ Euros, while in the range value we see that the difference between the smallest and the highest amount of the absorbed subsidies is $1,873,278.00$ Euros. The difference would surely have been less if one LAG that did not receive any subsidies were not included.

Table 3: Descriptive statistics of model variables

\begin{tabular}{|l|r|r|r|r|r|r|r|r|}
\hline & \multicolumn{2}{|c|}{$\begin{array}{c}\text { Total amount } \\
\text { of aid }\end{array}$} & $\begin{array}{c}\text { Size (number } \\
\text { of } \\
\text { inhabitants) }\end{array}$ & $\begin{array}{c}\text { Number } \\
\text { of } \\
\text { members }\end{array}$ & $\begin{array}{c}\text { Public } \\
\text { sector }\end{array}$ & $\begin{array}{c}\text { Economic } \\
\text { sector }\end{array}$ & $\begin{array}{c}\text { Civil } \\
\text { Cector }\end{array}$ & $\begin{array}{c}\text { Total } \\
\text { number of } \\
\text { within } \\
\text { employees }\end{array}$ \\
$\begin{array}{l}\text { agriculture, } \\
\text { forestry, } \\
\text { and fishing }\end{array}$ \\
\hline N Valid & 56 & 56 & 36 & 36 & 36 & 36 & 46 & 46 \\
\hline Missing & 0 & 0 & 20 & 20 & 20 & 20 & 10 & 10 \\
\hline Mean & 1196820.28 & 44150.05 & 68.53 & 16.56 & 30.69 & 21.28 & 13722.50 & 1288.20 \\
\hline Median & 1205189.14 & 38349.50 & 59.00 & 15.00 & 27.00 & 19.00 & 11900.50 & 953.00 \\
\hline Std. & 338338.23 & 27941.16 & 32.47 & 8.78 & 16.082 & 14.01 & 9091.35 & 1044.64 \\
Deviation & 1873278.00 & 111672 & 142 & 46 & 67 & 68 & 46736 & 3927 \\
\hline Range & .00 & 12930 & 28 & 6 & 9 & 7 & 3506 & 67 \\
\hline Minimum & 1873278.00 & 124602 & 170 & 52 & 76 & 75 & 50242 & 3994 \\
\hline Maximum & & & & & & & &
\end{tabular}

Source: authors

\section{The absorption capacity of municipalities and cities in LAG area}

The Croatian LAGs consist of 531 units of local self-government (121 cities and 410 municipalities), accounting for $95.50 \%$ of the total number of local selfgovernment units in Croatia. (HMRR, 2017) As the main goal of the program is the local development of rural areas, one of the membership requirements is that the local self-government units must have less than 25,000 inhabitants, and Croatia is a country where all municipalities and most of the cities are small and meet this criterion. Since such small places are mostly affected by deruralisation, i.e. youth leaving and moving to larger cities, often are older people who take leading positions. Most of them are not willing to learn new technologies and to create extra time to study peculiarities of new ways of financing local projects. Using EU funds for them is a new approach that changes well-established routines, so there are large differences among the effectiveness of local self-government units in applying for EU funds and including these subsidies in their budgets.

Due to all of the above mentioned, it will be interesting to explore if absorption capacity of LAGs is correlated with the history of integrating EU funds to budgets 
of municipalities and cities that are part of LAGs as foreseen by hypothesis that experience of municipalities with high administrative capacity could strongly influence absorption of subsidies by LAGs.

Table 4 shows the mentioned variable with the expected impact on the dependent variable.

Table 4: Variables and their effect on the dependent variable

\begin{tabular}{|c|c|c|c|}
\hline Variable name & Abbreviation & Source & Expected effect \\
\hline $\begin{array}{l}\text { Absorption capacity- } \\
\text { the amount of aid that } \\
\text { LAG withdrew from } \\
\text { the EU funds }\end{array}$ & Ab.cap.LAG & $\begin{array}{l}\text { On internet } \\
\text { websites } \\
\text { APPRRR }\end{array}$ & Dependent variable \\
\hline $\begin{array}{l}\text { The absorption capacity } \\
\text { of municipalities and } \\
\text { cities }\end{array}$ & Ap.cap.mun.cit. & $\begin{array}{l}\text { Ott, K., Bronić, } \\
\text { M., Stanić, B., } \\
2016 \\
\text { Ott, K., Bronić, } \\
\text { M., Stanić, B., } \\
2018\end{array}$ & + \\
\hline
\end{tabular}

Source: authors

Most of the LAGs (57.78\%) in their membership have cities and municipalities which in total withdrew less than 1 million Euros. This shows that most of the municipalities have no distinct administrative capacity that could significantly help LAGs, and on the other side if those few that show strong absorptive capacity really could transfer this capacity to LAGs they would be easy to distinguish.

Table 5 represents standard descriptive statistics indicators: the number of observations arithmetic mean, median, mode, standard deviation, range and minimum and maximum value of the variable.

Out of the 56 local action groups observed, for 46 of them, we identified data on the absorption capacity of cities and municipalities operating in their area. In some LAGs, entire municipalities and cities are not included, except for individual settlements, and for this reason, it was not possible to include those in the analysis as funds are registered in local budgets by cities and municipalities, not by settlements.

The average absorption capacity of cities and municipalities grouped by their membership in a particular LAG amounts to 1.23 million Euros. By calculating the median for this variable, we see that $50 \%$ of cities and municipalities grouped by affiliation to a particular LAG withdrew less than 0.79 million Euros, while the other $50 \%$ withdrew more. 
From the standard deviation we see that the average deviation from the average is 1.42 million Euros, whereas from the range value we read that the difference between the smallest and the highest amount of the drawn funds is 7.09 million Euros.

Table 5: $\quad$ Descriptive statistics of model variables

\begin{tabular}{|c|c|c|c|}
\hline & & $\begin{array}{c}\text { Total amount of } \\
\text { aid }\end{array}$ & $\begin{array}{l}\text { Absorption capacity of } \\
\text { cities and municipalities }\end{array}$ \\
\hline $\mathrm{N}$ & Valid & 56 & 46 \\
\hline & Missing & 0 & 10 \\
\hline & & 1196820.28 & 1.23 \\
\hline & & 1205189.14 & 0.79 \\
\hline & iation & 338338.23 & 1.42 \\
\hline & & 1873278.00 & 7.09 \\
\hline & & .00 & .00 \\
\hline & & 1873278.00 & 7.09 \\
\hline
\end{tabular}

Source: authors

\section{Statistical analysis of the influence of factors on the success of LAGs}

The regression model in our analysis has the following form:

LAG absorption capacity (EU aid) $=\mathrm{f}$ (size - number of inhabitants, number of members, membership structure - public, civil and economic, the structure of the economy - total number of employees, number of employees in agriculture, the absorption capacity of cities and municipalities)

Since relations between variables were used in the analysis, standardization of all variables has been made, so the dependent variable is the absorption capacity of the LAG per capita (EU per capita), thus eliminating the impact of the size, i.e. the number of inhabitants.

Before the regression analysis, a correlation matrix (Table 6) was made where it was seen from the beginning that there is a chance for an eventual problem of multicollinearity, i.e. linear correlation of independent variables.

We can see that the problem is present in variables that show the structure of membership: the share of the public sector, the share of the economic and of the civil sector in membership, since the coefficient of correlation for those variables is above 0.5 . This result is not surprising, because if one share of a sector increases, the share of other sectors should be smaller.

In order to prevent the problem of multicollinearity, further analysis will exclude the impact of the economic and civil sector. Namely, the economic sector encompasses companies and family farms whose owners are members of the civil 
sector. For this reason, these two sectors can be merged and then separated from the public. Also, the main goal of this research is to see if "colonization" by the public sector can be justified by the declared positive effect of their administrative capacity.

Table 6: Correlation matrix

\begin{tabular}{|c|c|c|c|c|c|c|c|c|c|}
\hline & & $\begin{array}{c}\text { Amount of } \\
\text { aid per } \\
\text { inhabitant }\end{array}$ & $\begin{array}{l}\text { Number of } \\
\text { members } \\
\text { per capita } \\
\end{array}$ & $\begin{array}{l}\text { Share of the } \\
\text { public sector } \\
\text { in } \\
\text { membership } \\
\end{array}$ & $\begin{array}{l}\text { Share of the } \\
\text { economic } \\
\text { sector in } \\
\text { membership } \\
\end{array}$ & $\begin{array}{l}\text { Share of the } \\
\text { civil sector in } \\
\text { membership }\end{array}$ & $\begin{array}{c}\text { Number of } \\
\text { employees } \\
\text { in total } \\
\text { population }\end{array}$ & \begin{tabular}{|c|} 
Share of \\
employed \\
persons in \\
agriculture \\
in the total \\
number of \\
employees \\
\end{tabular} & \begin{tabular}{|c} 
Absorption \\
capacity of \\
cities and \\
municipalit \\
ies per \\
capita \\
\end{tabular} \\
\hline \multirow{3}{*}{$\begin{array}{l}\text { Amount of } \\
\text { aid per } \\
\text { inhabitant }\end{array}$} & \begin{tabular}{|l|} 
Pearson \\
Correlation
\end{tabular} & 1 & & & & & & & \\
\hline & \begin{tabular}{|l|} 
Sig. (2- \\
tailed)
\end{tabular} & & & & & & & & \\
\hline & $\mathrm{N}$ & 56 & & & & & & & \\
\hline \multirow{3}{*}{$\begin{array}{l}\text { Number of } \\
\text { members per } \\
\text { capita }\end{array}$} & \begin{tabular}{|l|} 
Pearson \\
Correlation
\end{tabular} & $.402^{* *}$ & 1 & & & & & & \\
\hline & $\begin{array}{l}\text { Sig. (2- } \\
\text { tailed) } \\
\end{array}$ & .002 & & & & & & & \\
\hline & $\mathrm{N}$ & 56 & 56 & & & & & & \\
\hline \multirow{3}{*}{$\begin{array}{l}\text { Share of the } \\
\text { public sector } \\
\text { in } \\
\text { membership }\end{array}$} & \begin{tabular}{|l|} 
Pearson \\
Correlation
\end{tabular} & -.132 & $.576^{* *}$ & 1 & & & & & \\
\hline & $\begin{array}{l}\text { Sig. (2- } \\
\text { tailed) } \\
\end{array}$ & .338 & .000 & & & & & & \\
\hline & $\mathrm{N}$ & 55 & 55 & 55 & & & & & \\
\hline \multirow{3}{*}{$\begin{array}{l}\text { Share of the } \\
\text { economic } \\
\text { sector in } \\
\text { membership }\end{array}$} & \begin{tabular}{|l|} 
Pearson \\
Correlation \\
\end{tabular} & -.161 & $.689^{* *}$ & $.736^{* * *}$ & 1 & & & & \\
\hline & $\begin{array}{l}\text { Sig. (2- } \\
\text { tailed) } \\
\end{array}$ & .239 & .000 & .000 & & & & & \\
\hline & $\mathrm{N}$ & 55 & 55 & 55 & 55 & & & & \\
\hline \multirow{3}{*}{$\begin{array}{l}\text { Share of the } \\
\text { civil sector in } \\
\text { membership }\end{array}$} & \begin{tabular}{|l|} 
Pearson \\
Correlation
\end{tabular} & -.111 & $.674^{* *}$ & $.623^{* *}$ & $.882^{* *}$ & 1 & & & \\
\hline & $\begin{array}{l}\text { Sig. (2- } \\
\text { tailed) } \\
\end{array}$ & .421 & .000 & .000 & .000 & & & & \\
\hline & $\mathrm{N}$ & 55 & 55 & 55 & 55 & 55 & & & \\
\hline \multirow{3}{*}{$\begin{array}{l}\text { Number of } \\
\text { employees in } \\
\text { total } \\
\text { population }\end{array}$} & \begin{tabular}{|l|} 
Pearson \\
Correlation
\end{tabular} & -.263 & -.230 & -.024 & -.183 & -.220 & 1 & & \\
\hline & \begin{tabular}{|l|} 
Sig. (2- \\
tailed) \\
\end{tabular} & .078 & .124 & .873 & .224 & .141 & & & \\
\hline & $\mathrm{N}$ & 46 & 46 & 46 & 46 & 46 & 46 & & \\
\hline \multirow{3}{*}{$\begin{array}{l}\text { Share of } \\
\text { employed } \\
\text { persons in } \\
\text { agriculture in } \\
\text { the total } \\
\text { number of } \\
\text { employees } \\
\end{array}$} & \begin{tabular}{|l} 
Pearson \\
Correlation \\
\end{tabular} & .112 & -.001 & -.087 & -.041 & -.054 & -.079 & 1 & \\
\hline & \begin{tabular}{|l|} 
Sig. (2- \\
tailed) \\
\end{tabular} & .458 & .996 & .564 & .789 & .722 & .601 & & \\
\hline & $\mathrm{N}$ & 46 & 46 & 46 & 46 & 46 & 46 & 46 & \\
\hline \multirow{3}{*}{$\begin{array}{l}\text { Absorption } \\
\text { capacity of } \\
\text { cities and } \\
\text { municipalitie } \\
\text { s per capita }\end{array}$} & \begin{tabular}{|l|} 
Pearson \\
Correlation \\
\end{tabular} & -.131 & -.227 & -.109 & -.184 & -.191 & $.416^{* *}$ & .216 & 1 \\
\hline & \begin{tabular}{|l|} 
Sig. (2- \\
tailed) \\
\end{tabular} & .336 & .093 & .428 & .178 & .161 & .004 & .149 & \\
\hline & $\mathrm{N}$ & 56 & 56 & 55 & 55 & 55 & 46 & 46 & 56 \\
\hline
\end{tabular}

**. Correlation is significant at the 0.01 level (2-tailed).

Source: authors 
The regression model after standardization and release of variables has the following form:

The absorption capacity of LAG per capita (EU per capita) $=\mathrm{f}$ (number of members per capita, the share of the public sector in membership, the share of the total number of inhabitants, the share of employed in agriculture in total population, absorption capacity of cities and municipalities per capita )

Or:

Where is:

$$
\hat{y}_{i}=\beta+\beta_{1} x_{1}+\beta_{2} x_{2}+\beta_{3} x_{3}+\beta_{4} x_{4}+\beta_{5} x_{5}
$$

$\hat{y}_{\mathrm{i}}-$ Absorption capacity (aid) per capita

$\mathrm{x}_{1}$ - Number of members per capita

$\mathrm{x}_{2}$ - Share of the public sector in membership

$\mathrm{x}_{3}$ - Share of employees in the total number of population

$\mathrm{x}_{4}$ - Share of employees in agriculture in the total number of employees

$\mathrm{x}_{5}-$ The absorption capacity of cities and municipalities per capita

Table 7: $\quad$ Regression analysis results

\begin{tabular}{|l|l|l|l|l|l|}
\hline & \multicolumn{4}{|l|}{$\begin{array}{l}\text { Unstandardized } \\
\text { Coefficients }\end{array}$} & \multicolumn{2}{l|}{$\begin{array}{l}\text { Standardized } \\
\text { Coefficients }\end{array}$} \\
\hline & B & Std. Error & Beta & T & Sig. \\
\hline Constant of & 41.286 & 12.116 & & 3.408 & .002 \\
\hline $\begin{array}{l}\text { Number } \\
\text { members per capita }\end{array}$ & 8820.386 & 2394.048 & .595 & 3.684 & .001 \\
\hline $\begin{array}{l}\text { Public sector share } \\
\text { in membership }\end{array}$ & -99.216 & 30.050 & -.516 & -3.302 & .002 \\
\hline $\begin{array}{l}\text { Share of employees } \\
\text { in total number of } \\
\text { population }\end{array}$ & -20.388 & 34.475 & -.086 & -.591 & .558 \\
\hline $\begin{array}{l}\text { Share of employees } \\
\text { in agriculture in } \\
\text { total number of } \\
\text { employees }\end{array}$ & 17.855 & 28.064 & .085 & .636 & .528 \\
\hline $\begin{array}{l}\text { Absorption capacity } \\
\text { of cities and } \\
\text { municipalities per } \\
\text { capita }\end{array}$ & -64417.392 & 85405.098 & -.111 & -.754 & .455 \\
\hline
\end{tabular}

Source: authors

From the results of the regression analysis presented in Table 7, we can see the significance of the influence of two variables - the number of members per capita and the share of the public sector in membership, which results from the equation model:

$$
\hat{y}_{i}=41.286+8820.386 x_{1}-99.216 x_{2}
$$




\section{LEX LOCALIS - JOURNAL OF LOCAL SELF-GOVERNMENT

Where is:

ŷi - Absorption capacity (aid) per capita

$\mathrm{x}_{1}$ - Number of members per capita

$\mathrm{x}_{2}$ - Share of the public sector in membership

The model says that if there is an increase in the number of members within the LAG per one, the amount of funding per capita will increase to 8,820.386 Euros, assuming that the other variables do not change. On the other hand, if participation in the LAG membership of the public sector share increases by one percentage point, the amount of aid per capita will decrease by 99.216 Euros.

Standardized coefficient values with independent variables indicate that the variable number of members per capita has a slightly greater relative impact on the dependent variable.

Table 8: Evaluation of model representativeness

\section{Model Summary}

\begin{tabular}{|c|c|c|c|c|c|c|c|c|c|}
\hline \multirow[b]{2}{*}{ Model } & \multirow[b]{2}{*}{$\mathrm{R}$} & \multirow[b]{2}{*}{ R Square } & \multirow[b]{2}{*}{$\begin{array}{l}\text { Adjusted R } \\
\text { Square }\end{array}$} & \multirow{2}{*}{$\begin{array}{l}\text { Std. Error } \\
\text { of the } \\
\text { Estimate }\end{array}$} & \multicolumn{5}{|c|}{ Change Statistics } \\
\hline & & & & & $\begin{array}{l}\text { R Square } \\
\text { Change }\end{array}$ & F Change & df1 & df 2 & $\begin{array}{c}\text { Sig. F } \\
\text { Change }\end{array}$ \\
\hline , & $.595^{\mathrm{a}}$ & .354 & .273 & 15.25 & .354 & 4.377 & 5 & 40 & .003 \\
\hline
\end{tabular}

a. Predictors: (Constant), the Absorption capacity of cities and municipalities per capita, share of the public sector in membership, Share of employees in the total number of employees, Share of employees in the total number of population, Number of members per capita

b. Dependent Variable: Amount of aid per capita

Source: authors

The value of the coefficient of determination is 0.354 , which means that the model includes $35.4 \%$ of the squared sum deviation of the dependent variable from its arithmetic mean, resulting in the model is not representative. However, this indicator has the disadvantage that it is not unbiased, so its value is often ignored when evaluating the model.

Table 9: Assessment of model significance- ANOVA test

\begin{tabular}{|c|c|c|c|c|c|c|}
\hline \multicolumn{7}{|c|}{ ANOVA $^{\mathrm{a}}$} \\
\hline Model & & Sum of Squares & Df & Mean Square & $\mathrm{F}$ & Sig. \\
\hline \multirow[t]{3}{*}{1} & Regression & 5090.364 & 5 & 1018.073 & 4.377 & $.003^{\mathrm{b}}$ \\
\hline & Residual & 9303.845 & 40 & 232.596 & & \\
\hline & Total & 14394.208 & 45 & & & \\
\hline
\end{tabular}

a. Dependent Variable: Amount of aid per capita

b. Predictors: (Constant), the Absorption capacity of cities and municipalities per capita, share of the public sector in membership, Share of employees in the total number of employees, Share of employees in the total number of population, Number of members per capita

Source: authors 
From the results of the ANOVA test (Table 9) it results that the coefficient of significance is 0.003 which implies the significance of the model as a whole, for significantly less than $1 \%$.

And in the end, it remains to be explored, and thus to prove the absence of multicollinearity and heteroscedasticity.

Table 10: VIF and TOL values

\begin{tabular}{|l|l|r|r|}
\hline \multirow{2}{*}{ Model } & \multicolumn{2}{|c|}{ Collinearity Statistics } \\
\cline { 3 - 4 } & Tolerance & VIF \\
\hline 1 & (Constant) & .619 & 1.614 \\
\cline { 2 - 4 } & $\begin{array}{l}\text { Number of members per capita } \\
\text { Share of the public sector in } \\
\text { membership }\end{array}$ & .663 & 1.509 \\
\hline $\begin{array}{l}\text { Share of employees in the total } \\
\text { number of population }\end{array}$ & .773 & 1.294 \\
\hline $\begin{array}{l}\text { Share of employees in agriculture in } \\
\text { the total number of employees }\end{array}$ & .910 & 1.099 \\
\hline $\begin{array}{l}\text { The absorption capacity of cities and } \\
\text { municipalities per capita }\end{array}$ & .742 & 1.348 \\
\hline
\end{tabular}

Source: authors

The obtained values for VIF are less than 5 and for TOL greater than 0.2 , which proves that multicollinearity problem does not exist among the independent variables (Table 10).

Table 11: Value of non-standardized residual

\begin{tabular}{|c|c|c|}
\hline & & Unstandardized Residual \\
\hline \multirow{3}{*}{$\begin{array}{l}\text { Number of members } \\
\text { per capita }\end{array}$} & Correlation Coefficient & .023 \\
\hline & Sig. (2-tailed) & .878 \\
\hline & $\mathrm{N}$ & 46 \\
\hline \multirow{3}{*}{$\begin{array}{l}\text { Share of the public } \\
\text { sector in } \\
\text { membership }\end{array}$} & Correlation Coefficient & .045 \\
\hline & Sig. (2-tailed) & .768 \\
\hline & $\mathrm{N}$ & 46 \\
\hline \multirow{3}{*}{$\begin{array}{l}\text { Share of employees } \\
\text { in the total number } \\
\text { of population }\end{array}$} & Correlation Coefficient & .082 \\
\hline & Sig. (2-tailed) & .589 \\
\hline & $\mathrm{N}$ & 46 \\
\hline \multirow{3}{*}{$\begin{array}{l}\text { Share of employees } \\
\text { in agriculture in the } \\
\text { total number of } \\
\text { employees }\end{array}$} & Correlation Coefficient & -.018 \\
\hline & Sig. (2-tailed) & .906 \\
\hline & $\mathrm{N}$ & 46 \\
\hline \multirow{2}{*}{$\begin{array}{l}\text { Absorption capacity } \\
\text { of cities and }\end{array}$} & Correlation Coefficient & .098 \\
\hline & Sig. (2-tailed) & .517 \\
\hline
\end{tabular}




\begin{tabular}{|l|l|l|}
\hline $\begin{array}{l}\text { municipalities per } \\
\text { capita }\end{array}$ & $\mathbf{N}$ \\
\hline
\end{tabular}

Source: authors

All values of significance in Table 11 are greater than 5\% meaning that there is no correlation between residuals and independent variables, i.e. the problem of heteroscedasticity is not present in the model.

\section{Discussion}

It was expected that LAGs operating in the area of local self-government units that were active in attracting subsidies from EU funds, and so demonstrating strong absorption capacity, under the influence of this better administration of these municipalities, also will achieve greater absorption of subsidies, i.e. there was a positive influence expected. The results showed that there was no statistically significant correlation and that LAGs whose members were local units active outside the local group and had a higher part of EU funding in their budget were not more successful in attracting funds. So supposed higher administrative capacity of municipalities, was not transferred to the absorption capacity of LAGs.

It has also been verified to what extent the LAG absorption capacity is affected by the number and structure of the members, the size i.e. the number of inhabitants in the LAG area and the economic structure.

The share of employees in the total number of inhabitants is not statistically significant for the model. Also, in spite of the greater focus of the program on agriculture, the analysis did not confirm the potentially positive impact of the higher share of agricultural employment in the economic structure as the variable is not statistically significant.

However, two variables of the model are statistically significant. The first is the number of members per capita. The model says that if there is an increase in the number of members, assuming that the other variables do not change, there will be an increase in the number of subsidies per capita. Our analysis confirmed previous findings from Czech research on LAG technical efficiency (Vrabkova \& Šaradin, 2017).

Another significant variable is the one with which we tested the membership structure, i.e. the effect of the size of the public partner's share in the total membership of the LAG. Since this is a negative statistically significant relationship, the growth of the public sector share would lead to a decrease in the amount of absorbed subsidies per capita, assuming that the other variables do not change. 


\section{Conclusion}

Approaching the local development from the bottom, partnership, and cogovernance is an important part of the EU's regional and rural policy. LAGs are trisectoral bodies in which the economic and civil sectors in partnership with the public sector make it possible to accumulate and use resources through neo-endogenous rural development.

In such a decentralized approach to community-led local development based on the principle of subsidiarity, the municipalities may be considered central players, and their interaction with the LAG partnerships is of special interest. A certain degree of interaction between LAG and municipality is desirable, but there is a risk of exaggerating municipal interference, which can compromise the LEADER principles of self-governance and bottom-up development.

The LAG example in Croatia has shown that "colonization" and "municipalization" of local partnerships have no justifications, as increasing the share of public partners in the membership structure reduces effectiveness.

The basic assumption by which the leading public sector is trying to justify itself as having a better administrative capacity for attracting and absorbing subsidies has also been proven to be unjustified as there are no statistically relevant indicators that would suggest municipalities with stronger absorption capacity transfer it to the LAGs in which they participate.

The emphasis in the future should be on promoting the inclusion of the private sector (civil and economic), as only the activity of numerous motivated members from the private sector guarantees the greater success of the whole partnership.

\section{References:}

Argiolas, G., Cabras, S., Dessì, C, \& Floris, M. (2009) Building innovative models of territorial governance, Journal of Place Management and Development, 2(3), pp. 178210.

Bosworth, G., Annibal, I., Carroll, T., Price, L., Sellick, J. \& Shepherd, J. (2016) Empowering Local Action through Neo Endogenous Development; The Case of LEADER in England, Sociologia Ruralis, 56(3), pp. 427-449.

CEC (2005) Council Regulation No 1698/2005 of 20 September 2005 on support for rural development by the European Agricultural Fund for Rural Development (EAFRD).

Chevalier, P., Mačiulyté, J., Razafimahefa, L. \& Dedeire, M. (2017) The Leader Programme as a Model of Institutional Transfer: Learning from Its Local Implementation in France and Lithuania, European Countryside, 9(2), pp. 317-341.

Croatian LEADER Network, LEADER, available at http://www.lmh.hr/leader-clld/leader (July 2, 2018). 
Dax, T., Strahl, W., Kirwan, J. \& Maye, D. (2016) The Leader programme 2007-2013: Enabling or disabling social innovation and neo-endogenous development? Insights from Austria and Ireland, European Urban and Regional Studies, 23(1), pp. 56-68.

Esparcia, J., Escribano, J. \& Serrano, J. J. (2015) From development to power relations and territorial governance: Increasing the leadership role of LEADER Local Action Groups in Spain, Journal of Rural Studies, 42, pp. 29-42.

European Commission (2006) The LEADER approach (Luxembourg: Office for Official Publications of the European Communities).

European Court of Auditors (2010) Implementation of the LEADER Approach for Rural Development, Special Report No. 5 (Luxembourg: Publication Office of the European Union).

Farrell G., Thirion S. (2005) Social capital and rural development: from win-lose to winwin with the LEADER initiative, In: Schmied D. (ed) Winning and Losing: The Changing Geography of Europe's Rural Areas (Ashgate, Aldershot).

Halamska M. (2011) Sceny rozwoju lokalnego w Polsce: dekoracje i aktorzy, Wieś $i$ Rolnictwo, 4(153), pp. 103-120.

High C. \& Nemes G. (2007) Social Learning in LEADER: Exogenous, Endogenous and Hybrid Evaluation in Rural Development, Sociologia Ruralis, 47(2), pp. 103-119.

HMRR - Hrvatska mreža za ruralni razvoj (2017) Hrvatski LAG-ovi, available at: http://www.hmrr.hr/hr/leader/hrvatski-lagovi/ (February 14, 2018).

Knieć W. (2007) Władza w LGD, Kwartalnik Leader+, 4, pp. 18-19.

Kovach, I. (2000) LEADER, a new social order, and the central eand East-European countries, Sociolgia Ruralis, 40(2), pp. 181-189.

Kovach, I., Kucerova, E. (2006) The project class in central Europe: the Czech and Hungarian cases, Sociologia Ruralis 46(1), pp. 3-21.

Lacquement, G. \& Raynal, J. (2013) Acteurs et ressources du développement local en Allemagne orientale : le territoire rural au prisme des projets du programme européen LEADER, Annales de géographie, 692(4), pp. 393-421.

Lopolito, A., Nardone, G. \& Sisto, R. (2011) Towards a comprehensive evaluation of local action groups in LEADER programmes, New Medit, 10(1), pp. 43-49.

Łukasz Sykała, L., Dej, M. \& Wolski, O. (eds) (2015) The LEADER Method. Transferring Experience of the Visegrad Group Countries to Georgia (Krakow: Institute of Urban Development).

Ministry of Agriculture (2014) Rural Development Programme of the Republic of Croatia for the Period 2014-2020, available at https://ruralnirazvoj.hr/files/documents/Programme_2014HR06RDNP001_6_1_hr.pd f (February 10, 2019).

O'Keeffe, B. (2009) Regional and Local Devolution in Ireland - the Potential of LEADER Partnerships to Provide Municipal Government, Lex Localis-Journal of Local Self-Government, 7(3), pp. 257-269.

Ott, K., Bronić, M., Petrušić, M. \& Stanić, B. (2016) Budget transparency in Croatian counties, cities and municipalities (November 2015-March 2016), Newsletter: povremeno glasilo Instituta za javne finacije, 17(108), pp. 1-11.

Ott, K., Bronić, M., Petrušić, M. \& Stanić, B. (2018) Budget transparency in Croatian counties, cities and municipalities (November 2017-March 2018), Newsletter: povremeno glasilo Instituta za javne finacije, 19(115), pp. 1-14.

Ray C., (2000), Endogenous socio-economic development in the European Union - issues of evaluation, Journal of Rural Studies, 16(4), pp.447-458. 
Ray C., (2006) Neo-endogenous rural development in the EU, In: Cloke P., Marsden T. \& Mooney, P. (eds) Handbook of Rural Studies, (London: Sage).

Teilmann, K. A. \& Thuesen, A. A. (2014) Important Types of LAG-Municipality Interaction When Collaborating on Rural Development: Lessons from Danish LEADER LAGs, International Journal of Rural Management, 10(1), pp. 21-45.

Vrabková I. \& Šaradín P. (2017) The technical efficiency of local action groups: a Czech Republic case study, Acta Universitatis agriculturae et silviculturae Mendelianae Brunensis, 65(3), pp. 1065-1074.

Zajda, K. (2014) Problems of functioning of Polish local action groups from the perspective of the social capital concept, Eastern European Countryside, 20(1), pp. 73-97. 